\title{
IMRE ROSENBERG \\ A Portrait of One Member of the Refugee Status Advisory Committee: His Life and His Work on the Committee
}

\section{$\mathbf{T}$} he Task Force on Immigration Practices and Procedures finds room for improvement in Canada's procedures for refugee determination. The branch office for Canada of the United Nations High Commissioner for Refugees has reservations about the separation of information gathering from decision making on refugee claims in Canada. Three-quarters of refugee claims here are turned down. What do these things mean? Very little, says Imre Rosenberg, in terms of how well the system actually works.

Rosenberg has packed a lot of experience into his 68 years, including a major role in sorting out the mass relocation of humanity in Eastern Europe at the end of World War II; arrival in post-war Canada as a political refugee; and serving, for the past fifteen months, on the Refugee Status Advisory Committee (RSAC). A life-long concern for the well-being of his fellow man leaves him perfectly confident, at his age, to pass judgement on matters humanitarian. Rosenberg can say of the RSAC without the slightest hint of embarrassment: "We make our decisions in what is as close to a good decision-making system as humans can produce."

Yes, he'll acknowledge, of course the committee is always asking for more people. "But there is a limit to how much can be spent." Yes, the translation service could use improvement. And yes, of course it would be ideal if we could have oral hearings for refugee claimants. "It might be possible for the Immigration Appeal Board to hear more appeals - I wouldn't know about that but for the RSAC, oral hearings would simply be technically impossible to organize: We can't go to Gander to interview a Czech getting off a plane. People from Manila are landing at Winnipeg; Central Americans generally land at Calgary, Edmonton or Toronto ...

But when it comes to the real issue, to the ability of the RSAC to act fairly .. mild-mannered scientist Bruce Banner's transmogrification into the avenging Hulk has nothing on the metamorphosis of this normally affable and dapper man when he reflects on poorly-informed criticism of the RSAC's record. His soft . voice becomes a shout and tears well in his eyes. "The claim that the vast majority of refugee applications are turned down is grossly misleading. Thousands of people want to come to Canada, by any means available to them, and when some thousands come from a democratic country - like India - it Imre Rosenberg sketching an excavalion from the 1st century B.C., near Tivon, larael.

\section{By Robert Marshall}

not only distorts the picture, but breaks down the machinery. It really has nothing to do with the RSAC."

Rosenberg's affirmation is heartfelt: "I think we bend over backwards to be fair, to give more than the benefit of the doubt to the claimant, because we always think of the loss to the person forced to leave his home. Perhaps most people don't think that way, but we do."

Imrich Yitzhak Rosenberg. Born in Nove Mesto, Slovakiá; May 22, 1913. Active in national Jewish youth movement. Doctorate in government and law, Bratislava University, 1939 after two interruptions to work underground against Hitler. While attending the Academy for International Law in The Hague, he helped organize the escapes of Jews from Czechoslovakia and Berlin in 1939.

"I landed in England the day before the war broke out, to buy a boat to move refugees," he recalls. Ensconsed in his comfortable apartment with its superb view of the frozen Ottawa River, he is surrounded by evidence of his wife's impeccable decorative taste and the watercolours he himself has painted. The outbreak of war in Europe seems a long way off, but Rosenberg knows that time intimately and the words come easily.

"Every decent person who was safe in London wanted to join a unit fighting Hitler." He joined the Czech army and helped build the London-based resistance movement, led by Edvard Benes, which was eventually recognized as the legitimate democratic governmentin-exile in Czechoslovakia.

In 1944, as the war neared its end, Rosenberg went to Moscow on behalf of the Czechoslovak government and the

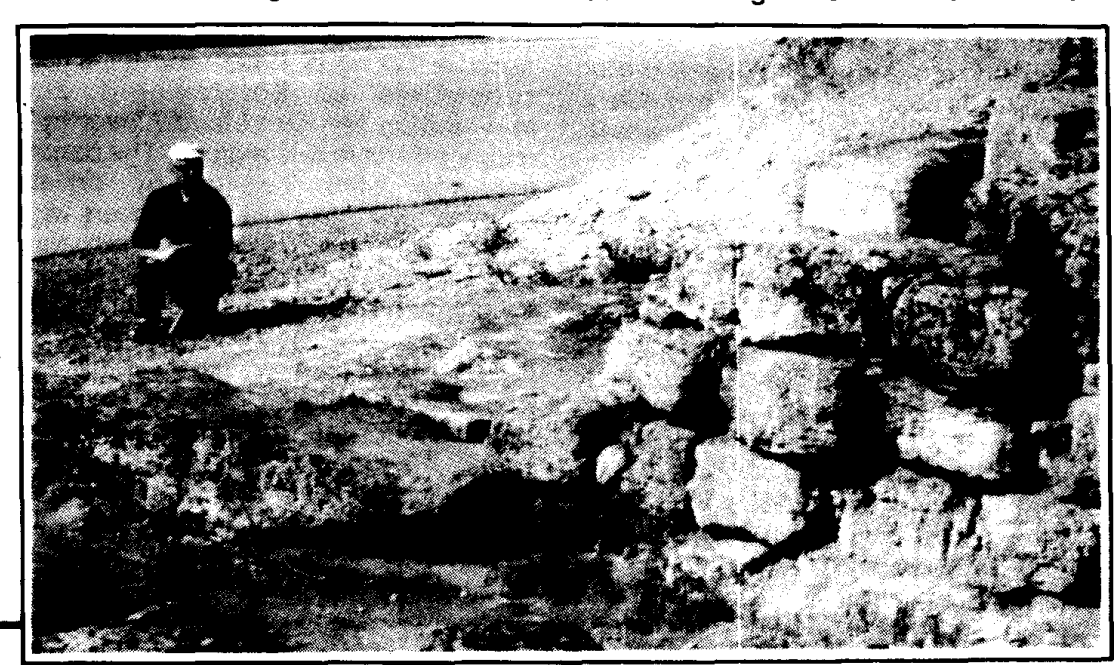

World Jewish Congress on a mission which, had it succeeded, could have changed the course of Jewish history since the war. "I was asked to go to Moscow to make arrangements whereby Soviet Jews would take part in the Congress in some form. Believe it or not, you're talking to a man who nearly succeeded. The party - and not just functionaries, but the party itself agreed that if Soviet Jews could get 50 percent of the seats on the executive of the World Jewish Congress, then Soviet Jews would participate in the Congress. That was long before the Soviets agreed to participate in anything internationally. When I heard they were even considering it I could not believe it. Soviet Jews participating in a forum in New York - it would have been like a revolution."

Unfortunately Rosenberg's hopes were dashed. He now feels the agreement was reached during one of the Stalin regime's spells of appeasement toward Jews and was abandoned with the return of the more typical mood of hostility.

He headed for Czechoslovakia as the war ended, travelling with the Soviet Army as it liberated concentration camps in Poland, Germany, Austria and Czechoslovakia. "The world that had been closed in by the Nazis was being opened up. I was one of the first people to visit Theresienstadt camp, north of Prague, and I selected 301 orphaned children for transfer to England. The British Home Office sent 16 planes to pick them up. I also chose adults, most of them already with relatives in England, to accompany the children about one for every ten children."

There was also a steady stream of Jews arriving in Czechoslovakia from 
work camps in Germany's Ruhr valley. "I don't think there is another living person who has seen as much as $I$ in terms of broken people who survived the camps." He says now in a tone of wonder, "I was a young man when I was doing these things - today I think it was impossible. You're dealing with 180,000 people moving across the border. We gave them medical help, money, tickets. I organized whole trainloads of refugees."

Rosenberg was also dealing with queries from abroad on the whereabouts of missing people. His responses had a depressing similarity. In a letter from Kostice in eastern Slovakia, dated May 3, 1945, Rosenberg wrote to the Jewish Agency for Palestine in Jerusalem: "I have received your letter of 5th March and have sent a message to our representative in Carpathian Ukraine, asking him to ascertain the whereabouts of the persons you mentioned... Generally I would say that most of the Jews in Carpathian Ukraine have been killed ...."

Rosenberg worked at organizing a department of social welfare for the post-war Czechoslovak government, but was not optimistic. "I said to anyone willing to listen that Jews had no future in Central or Eastern Europe, it was a matter of months or years before they would have to leave." They did.

He himself was soon in a dispute with the Czechosiovak government over its refusal to release Jewish manuscripts and the priceless art treasures the Nazis had looted from synagogues and Jewish museums in occupied Europe. Even now he is bitter that, although the Czechoslovak gold has been returned to Prague from London and Washington, the Czech authorities will not let the Jewish treasures go to Israel where he feels strongly they belong.

With the Communist coup of February, 1948, he was forced to flee. "I heard about (Foreign Minister Jan) Masaryk's death from a street cleaner at seven in the morning, though the government didn't announce it until the afternoon. He was pushed from a window; there is proof. I slipped out of the country but my first wife made a mistake and she was caught. She was in jail, terrible jail, for twelve years."

Having learned he'd been sentenced in absentia to life imprisonment, Rosenberg spent a year in England waiting for a Canadian visa. ("In those days," he grins, "you didn't get what you are getting today - which is instantaneous help.") When he arrived in Ottawa as a landed immigrant he was turned down by the Civil Service Commission and instead worked as a laborer, carrying vegetables in Byward Market. Eventually he started lecturing at Ottawa University and selling houses. becoming a partner in a successful real estate company. Along the way he donated $\$ 12,000$ to establish a home for international students and public servants ("so others would not be left out in the cold in Ottawa, as I was"); married his present wife, Truda, a psychologist with her own story to tell about life in war-time Poland and Germany; and earned an M.A. in Soviet studies at Carleton. They lived in Israel for seven years while Rosenberg worked first with Haifa University and later with the Prime Minister's office in Jerusalem, but returned to Ottawa in 1978.

$O^{r}$ day at the end of 1980 , Rosenberg was asked if he would accept a position with the RSAC. And he has had no regrets. "I really took to it," he says. "I was pleasantly surprised at first that all the public servants I dealt with leaned over backwards to help refugees. I always told my wife I had never seen such humanity in other public services as I did here."

The RSAC hatd beerroperating since 1978 and, Rosenberg says, "as we went along in our work we tended to improve it, moving from intuition or guesswork to a higher level based more on facts than intuition." He now sits on a panel at least once and usually two days a week, at each meeting considering approximately ten applications. Each case requires extensive reading, starting with a lengthy transcript of the claimant's interview with an immigration officer, accompanied by copies of all relevant documents. Often there is outside research too, from Amnesty International's Annual Report for example, and other sources. "After a week of this work you feel you have seen all the troubles of the world in miniscule," he says. "Though I have travelled a great deal, I had always seen Ethiopia, for instance, as one country. Now I recognize it as a complex grouping of nationalities. So each of these cases means good-sized studies."

$\mathrm{He}$ is confident that the committee will continue to be motivated by this "steady desire to improve the level of the decision-making process," and he is very supportive of Employment and Immigration Minister Lloyd Axworthy's recent efforts in this regard: "The panels are now often chaired by private members, and new private members were chosen for their fairness; their long involvement in social work, refugee programs and projects; their international experience, etc."

Rosenberg doesn't just think, he knows the system works well. He is not beyond resorting to a little hyperbole to back his insistence that refugee claimants get every possible chance to succeed: "I would say that in Canada if a person tried fifty times to be recognized as a refugee and failed, there would still be a chance of recourse." And he quotes a UNHCR official from Geneva as saying Canada has "the world's most advanced and most human system of (refugee) determination."

osenberg has painted all his life. He worked with artists as a boy and likes to say, "Had it not been for Hitler, I would have been a painter all my life." He sometimes talks in painter's terms, of seeing perspective as well as detail in matters before him. His watercolors of scenes around Ottawa, Israel, Hawaii and Spain adorn his apartment and his wife's clinic.

The painter in Imre Rosenberg must have been pleased then, by a trip he made recently to Montreal to talk to forty "do-gooders" involved with refugee applications. "There was a growing wish to cause embarrassment to the federal government. I said I thought there had simply been a communication gap and that I would not be serving on the committee if 1 thought it wasn't fair. They felt they were being left out and i said if you have a problem, this is what you do. I do know that after I spoke to them the expected demonstrations did not take place, and the people I met took part in the Toronto meeting." Everything back in perspective, as in a painting properly composed. $\square$

\section{RSAC to be Independent of CEIC}

Several administrative changes in the refugee status determination process were announced by Lloyd Axworthy, Minister of Employment and Immigration, at the National Symposium on Refugee Determination. One was the issuance of new guidelines to the Refugee Status Advisory Committee (RSAC), discussed on page 5. The other involved structural changes in the RSAC, making it independent of the Canada Employment and Immigration Commission. It will have its own resources and an increased secretariat with better research capabilities; the number of private members will be increased from seven to ten (in November the number of private members had been increased from four to seven); and the Immigration and External Affairs officers serving on the RSAC will be appointed by the Minister and serve full time. In the context of these changes all existing appointments are being reviewed, and Kenneth Brown has resigned as Chairman.

The Minister has also issued a directive with respect to the screening of "manifestly unfounded claims". The RSAC will henceforth give full attention to every claim, with the exception of claims from countries where every claim from that country has been found to be invalid since the establishment of the RSAC. These the RSAC may continue to deal with through summaries.

These changes are based on recommendations in the report of the Task Force on Immigration Practices and Procedures on the Refugee Status Determination Process. 